\title{
非定常かく乱に対するディフューザ内はく離流れの応答*
}

\author{
望月修*1, 木 谷勝*1 \\ 志摩 祐 介 $^{* 2}$, 斉藤 朋 宏*3
}

\section{Response of Separating Flow in a Diffuser to Unsteady Disturbances}

Osamu MOCHIZUKI, Masaru KIYA, Yusuke SHIMA and Tomohiro SAITO

\begin{abstract}
The response of a separating flow in a two-dimensional diffuser to an unsteady disturbance is investigated. The disturbance is generated by the turbulent wake of a circular cylinder moving in front of the entrance of the diffuser. Thus the disturbance makes an angle to the main-flow direction. The pressure recovery coefficient, time-mean velocity distribution and phase-averaged velocity distribution are obtained for several disturbances with different frequencies and different angles. Reynolds number based on the velocity of the main flow at the inlet of the diffuser and its height is $5.2 \times 10^{4}$. The pressure recovery coefficient is found to be modified by the disturbance, depending on the frequency of the disturbance. The local deceleration and acceleration are observed near the wall of the inlet of the diffuser due to the disturbance. Thus the disturbance generated by the wake acts as an oscillator to induce a velocity fluctuation at a specific area.
\end{abstract}

Key Words: Unsteady Flow, Diffuser, Separation, Turbulence, Phase Averaging, Pressure Distribution, Wake, Fluid Machinery

\section{1.は じめに}

流体機械の使用環境, 使用法の変化が騒音・振動お よび効率低下を引き起こすことがある。例えば，ター ボ機械が最も最適な状態で使用されていれば, はく離 が原因となる騒音や振動が発生することはないが, 設 計点からはずれた状態で用いられる場合には，たとえ 最適設計されたものでもその限りではない.また，使 用環境が時間的に不規則に変化するような場合には， 使用者が当初に設定した流入流出条件を，そのつど調 整し直すなどということはないであろう。このよう に，機械そのものの設計が原因ではなく，不適な使用 が原因の, 効率低下および騒音増加の例が, むしろ多 いのである。このような騒音および抵抗を低減するた めに, はく離を能動制御する技術の確立が重大な課題 となっている(1) (5). 使用環境変化や使用状況変化に, 機械自身がそれを察知して自動的に対応し，常に最適 設計状態を保つようになっていれば, 効率を損なうこ となく，騒音・振動問題に対処できると考えられる.

* 原稿受付 1996 年 5 月 27 日

*1 正是, 北海道大学卫学研究科(亚060 札幌市北区北 13 条西 8 丁田)

*2 川崎重1:(株) (画673 明不市川崎町 1-1).

*3 寒土重1:(株) (画320 宇都宮方陽南 1-1-11)。
このような流れの制御方法の確立が本研究の目的で ある。これを実現する第 1 段階として, 周期的に流入 する非定常かく乱に対するはく離流れの応答特性を調 ベた. 本実験では, はく離を伴う片開き二次元ディフ ューザを用い, 周期的に円柱後流をディフューザ入口 に流入させた。このようなかく乱によってはく離流れ がどのように変化するかを, 位相平均法を用いた速度 場測定, 壁面静圧分布の測定によって明らかにした。 円柱後流の流入によりはく離が抑制され,ディフュー ザの圧力回復率が向上することがわかった. また,こ の非定常かく乱はディフューザ入口付近の壁面近く に, 局所的な速度変動を誘起することがわかった。

\section{2. 実験装置および実験方法}

$2 \cdot 1$ 供試ディフューザ 供試ディフューザの概 略と座標を図 1 に示す。供試ディフューザ内におい て, はく離が生じるような開き角, 面積比および長さ を設定した ${ }^{(6)}$. 供試ディフューザは, 入口高さ $H_{1}=65$ $\mathrm{mm}$, 出口高さ $H_{2}=130 \mathrm{~mm}$, 幅 $W=260 \mathrm{~mm}$, 長さ $L$ $=178.5 \mathrm{~mm}$ の片開き二次元ディフューザである。し

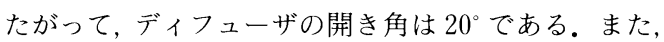
入口におけるアスペクト比 $\left(W / H_{1}\right)$ は 4.0 , 入口と出 口の面積比 $A R\left(=A_{2} / A_{1}\right.$, ここに, $A_{1}=H_{1} W, A_{2}=$ 


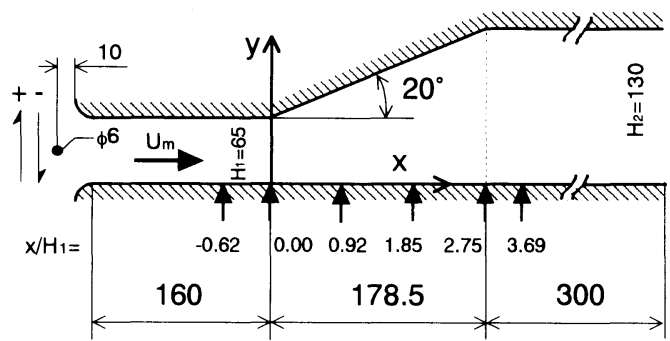

Fig. 1 Coordinate system and definition of symbols. Dimensions in $\mathrm{mm}$. Stations of measurement are indicated by $\uparrow$

$\left.H_{2} W\right)$ は 2.0 である。この結果, 供試ディフューザの 設計压力回復率は $C_{p} \fallingdotseq 0.52$, ディフューザ有効度 $\eta\left\{=C_{p} /\left(1-1 / A R^{2}\right)\right\}$ は 0.69 である(6). 以後, 簡単の ために角度 $20^{\circ}$ で下流方向に対して傾いている壁面を 「傾斜壁面」，これと対面する流れ方向に平行な壁面を 「水平壁面」と呼ぶことにする。なお, 供試ディフュ ーザの上流にはベルエントランスをもつ長さ $160 \mathrm{~mm}$ の直線流路 (以後, 入口流路と呼ぶ)が取付けられてい る.

図 1 に示されているように, ディフューザ入口の水 平壁面上に座標原点をとり，流れ方向を $x$ 軸，これと 直角な方向を $y$ 軸とする. 図中のヤで示された $x$ 方 向位置は, 実験結果を示す代表断面の位置を示してい る.

$2 \cdot 2$ かく乱の導入 供試ディフューザは吸込式 風路に取付けられ，空気がディフューザ上流に取付け られた直線流路のベルエントランスから流入する。こ の流入する流れに周期的かく乱を与えるために, 図 2 に示すように，モー夕の回転軸に直角に放射状に取付 けられた 4 本の直径 $D=6 \mathrm{~mm}\left(D / H_{1}=0.092\right)$ のジュ ラルミン製中空円柱を, ベルエントランス上流で回転 させた. ベルエントランスから円柱の中心までの距離 は $10 \mathrm{~mm}$ である. 円柱の回転中心は，ディフューザ の幅方向の中心から, $320 \mathrm{~mm}$ 離れている. 円柱が流 れを直角方向に周期的に通過する周波数 $f \mathrm{~Hz}$ は 1 秒 間当たりのモー夕回転数の 4 倍, すなわち $f=4 n / 60$ [数字の 4 は円柱の本数, $n$ はモー夕の回転数 (rpm)] である。したがって，円柱がベルエントランス付近の 流れを横切る際に形成される後流は, 周波数 $f$ でディ フューザに流入することになる。本実験では，この周 期的に流入する後流を周波数 $f$ の非定常かく乱と呼 ぶ. 本実験装置で与えられる最大の $f$ は $34 \mathrm{~Hz}$ であ る.

円柱の後流は, 図 3 に示すように, $x$ 方向に対して

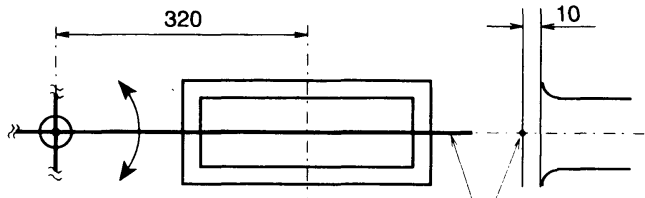

BELL MOUTH CIRCULAR CYLINDER

MOTOR

Fig. 2 Generator of unsteady disturbance using circular cylinders. Dimensions in $\mathrm{mm}$

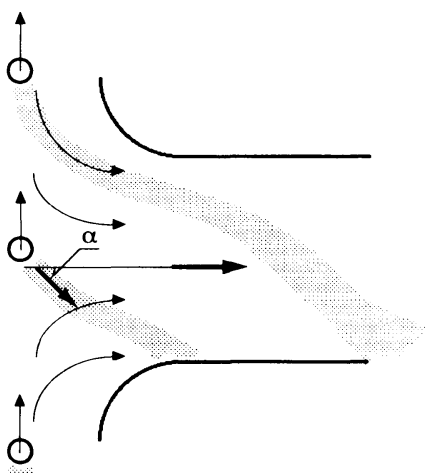

Fig. 3 Schematic figure of wake entering into inlet

傾いてディフューザに流入する．後流の $x$ 方向に対 する傾き角 $a$ は, ディフューザの幅方向の中心位置に おける円柱の移動速度と円柱が移動する位置の流速に よって決まる。したがって, 円柱の移動速度が大きい ほど後流の傾き角度は大きい. 供試ディフューザは片 開きディフューザであるために，かく乱の流入方向 （土a）によってその性能が影響を受ける可能性があ る.したがって，かく乱の流入方向，すなわち円柱の 移動方向を区別して央験を行う必要がある. 円柱が $y$ の正の方向に移動する場合を正の周波数で表し，逆の 方向に移動する場合を負の符号を付けた周波数で表 す.

周波数 $f$ の非定常かく乱がディフューザ内の流れ にどのような影響を及ぼすかを調べるために, ディフ ユーザ内で測定された速度信号を位相平均し，各位相 ごとに流れ場のようすを観測した。位相平均する際の 基準信号として, 円柱がベルエントランスを通過する 際に, 円柱が光経路を遮断することによって発生する 信号を用いた．円柱の移動方向の違いを区別するため と, 円柱のベルエントランス前面の移動速度の確認の ために, 一対の発光器および光センサをベルエントラ ンス両側にそれぞれ取付けてある。通過に伴う信号を パルス信号として取出し，それをトリガ信号，円柱の 
移動時間測定信号として用いた。

$2 \cdot 3$ 測定方法 本実験では, 壁面静圧 $p$, 時間平 均速度 $\bar{u}$ および速度変動の $\mathrm{rms}$ の值 $u^{\prime}$, および位相 平均速度 $\tilde{u}$ を測定した. ディフューザ壁面の幅方向 の中心線上にあけられた直径 $0.8 \mathrm{~mm}$ の静圧孔に, 心゙ ッツ形マノメータを接続して壁面静圧を測定した。な お, 同じ $x$ 断面内における傾斜壁面および水平壁面上 で測定された静圧の平均值を, その断面における壁面 静圧 $p$ とした。

速度測定には I 形熱線プローブを用いた。主流速度 は, 円柱の有無にかかわらず，次式に示すようにして 求められた $x / H_{1}=-0.62$ の位置に打ける平均速度 $U_{m}$ を代表速度として用いた。

$$
U_{m}=\frac{1}{H_{1}} \int_{0}^{H_{1}} \bar{u} d y
$$

円柱によってかく乱を与えないときの $U_{m}$ は 12 $\mathrm{m} / \mathrm{s}$ であり，このときの主流の乱れ強さは約 $1 \%$ あ゙あ る.レイノルズ数 $\operatorname{Re}\left(=H_{1} U_{m} / v\right.$, ここにvは空気の 動粘性係数）は $5.2 \times 10^{4}$ である.ディフューザ入口に おける境界層の厚さ $\delta$ は $6.9 \mathrm{~mm}\left(\delta / H_{1}=0.11\right)$ である. また, 排除厚さ $\delta^{*} は 0.92 \mathrm{~mm}\left(\delta^{*} / H_{1}=0.014\right)$, 運動量 厚さ $\theta$ は $0.51 \mathrm{~mm}\left(\theta / H_{1}=0.0078\right)$ である.したがっ て, 形状係数 $H_{12}\left(=\delta^{*} / \theta, \delta^{*}\right.$ : 排除厚さ, $\theta$ : 運動量 厚さ）が 1.8 であるから入口における境界層は遷移領 域にあるものと考えられる。

ディフューザ内の流れの様子を, 水槽において水素 気泡法を用いて可視化した。このときのディフューザ 模型は, 図 1 に示したものと同じ寸法のものである。 ディフューザ入口における主流の速度は $0.1 \mathrm{~m} / \mathrm{s}$ であ り,レイノルズ数は $5.7 \times 10^{3}$ である。風洞実験のレイ ノルズ数とは1けた異なるが, これらのレイノルズ数 におけるはく離の状況には, 大きな差違はないと考え られる(7)。

\section{3. 実 験 結 果}

$3 \cdot 1$ 壁面静圧分布 無かく乱の場合 $(f=0 \mathrm{~Hz})$ と，かく乱を与えた場合における壁面静压 $p$ の $x$ 方 向分布を、比較したものを図 4 に示す。ディフューザ 入口の上流位置 $\left(x / H_{1}=-0.62\right)$ において測定された 静圧 $p_{0}$ からの差として表した。各 $x / H_{1}$ 位置における 静圧の值は, それぞれ 3 回計測を行った平均值であ る. 実線だけで示したものは, ベルヌーイの定理から 求めた理論圧力変化である.

かく乱を与えない場合, ディフューザ内の壁面静圧 はほとんど上昇しないことがわかる，これは, 後で図 7 に示すディフューザ内の流れの可視化結果からもわ
かるように, 傾斜壁面側において大きなはく離が生じ ているためである.

これに対し, 周波数 $f$ の非定常かく乱がディフュー ザ内に流入すると, ディフューザ内のいずれの $x$ 断面 に扔いても，壁面静圧は上昇することがわかる．非定 常かく乱の周波数が高いほど，その上昇は大きい.な お，このかく乱を与える円柱の移動方向による違いは ほとんど認められない.すなわち, 円柱後流のディフ ユーザ入口流路に対する傾き角度より，単位時間当た りに流入する回数(周波数)のほうが壁面圧力上昇に影 響することを示唆している。

ディフューザ前後の壁面静圧の差から,ディフュー ザの圧力回復率 $C_{p}$ を $\left(p_{e}-p_{0}\right) /\left(\rho U_{m}{ }^{2} / 2\right)$ と定義する. ここに, 壁面圧力 $p_{e}$ は $x / H_{1}=5.1$ の断面で測定され た圧力である．周波数に対する圧力回復率の変化を図 5 に示す。本実験における測定範囲内では, いずれの 周波数でも無かく乱の場合より圧力回復率は増加する ことがわかる.また，周波数が高いほど $C_{p}$ は大き い. 図 5 に示した範囲では, $f=30 \mathrm{~Hz}$ のとき最大圧 力回復率を示す. 周波数の増加に伴い, 圧力回復率も どこまでも増加するとは考え難いので, 最大圧力回復 率を示すかく乱の最適周波数が存在するものと想像で きる，ただし，本実験装置では， $f= \pm 34 \mathrm{~Hz}$ 以上の周 波数を与えることができないので，最適周波数の確認 はできていない.

$3 \cdot 2$ 時間平均速度分布 非定常かく乱の流入に よるディフューザ内の時間平均速度場の変化を, 無か く乱時のものとともに図 6 に示す. 速度の測定には I 形熱線プローブを用いているため, はく離領域におけ

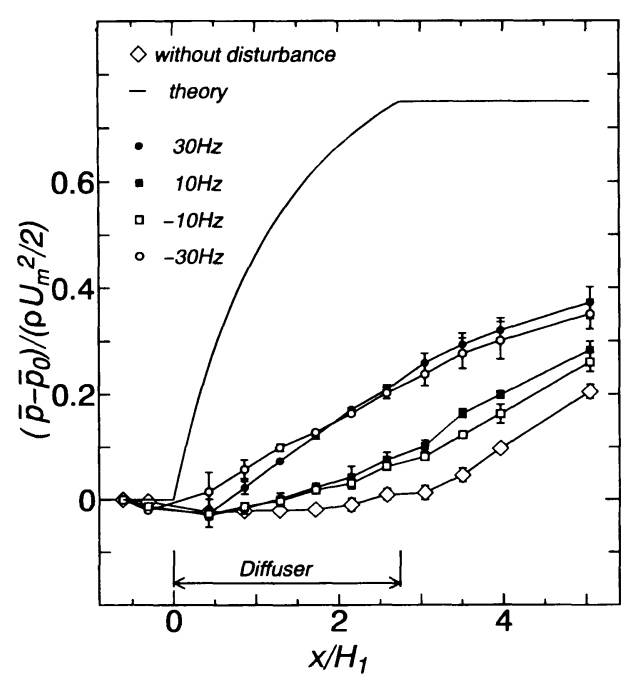

Fig. 4 Static pressure distributions. I : Uncertainty 


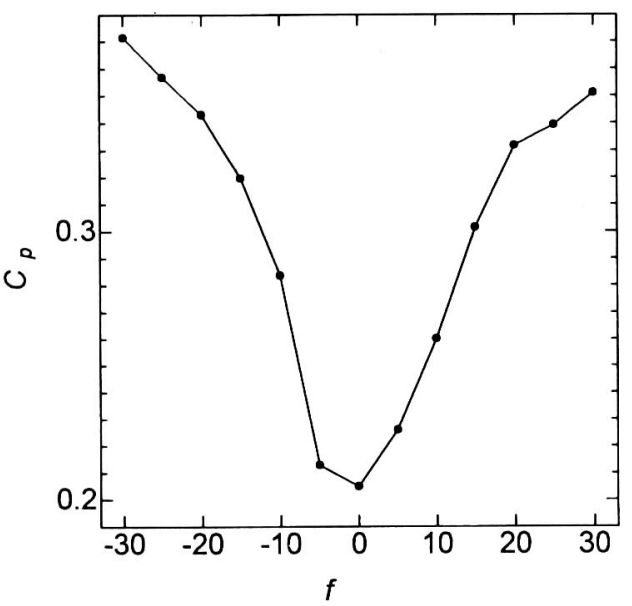

Fig. 5 Pressure recovery coefficient versus frequency of disturbance

る逆流が示されていない。しかし，無かく乱時におけ る逆流の存在は, 風洞実験における夕フト法によって 確認されている(8). また, 図 7 に示す水素気泡法によ る可視化によっても確認できる。無かく乱時における はく離領域の速度分布 [四 6(a)] を見ると, 傾斜壁 面近くの速度の值は小さく，ほほ一定值を示す。また， はく離せん断層に相当する位置の速度分布には変曲点 が存在し, その付近において乱れ強さは極大值を示 す。速度および乱強さ分布のこのような特性は，は く離領域に特幑的なものである。

周波数 $f=10 \mathrm{~Hz}$ の非定常かく乱が流入すると［図 6(b)], はく離領域が縮小寸る. 例えば, $x / H_{1}=1.85$ の断面に扔ける速度分布を無かく乱時のものと比較す ると, 主流における最大速度が減少し, 変曲点付近の 速度こう配が緩やかとなるとともに乱れ強さが極大值 を示す位置が傾斜壁面側に近づき, 傾斜壁面側の速度

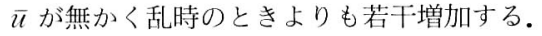

非定常かく乱が上述と同じ周波数ではあるが, 逆方 向から流入する場合にも, はく離領域が減少している ことが認められる。なお, 各断面の速度分布は $f=10$ $\mathrm{Hz}$ のものとほとんど差が認められない.すなわち， 非定常かく乱の流入方向の時間平均速度場に与える影 響は小さいことがわかる。

非定常かく乱の流入周波数を $30 \mathrm{~Hz}$ に増加させる と [図 6(c) ], 無かく乱時に比較して, 最大速度の減 少, 傾斜壁面近くの速度の増加, 乱れ強さの極大值の 位置が傾斜壁面に近づくこと，などが認められる。例 えば, 無かく乱時の $x / H_{1}=1.85$ の断面において, 明確 に認められたはく離を示す速度および乱れ強さの分布

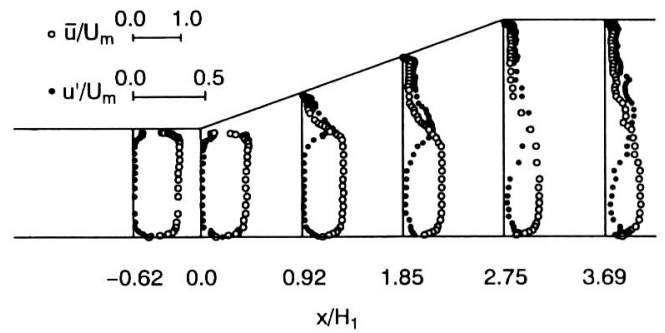

(a) Without disturbance

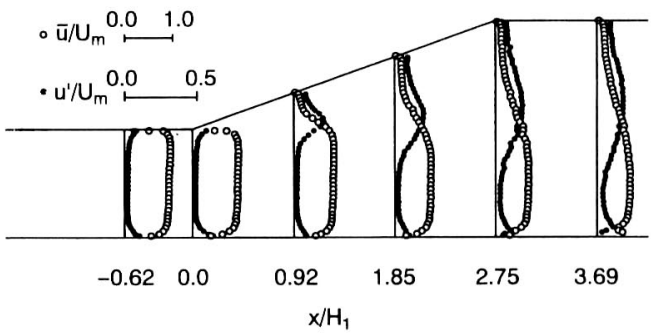

(b) $10 \mathrm{~Hz}$

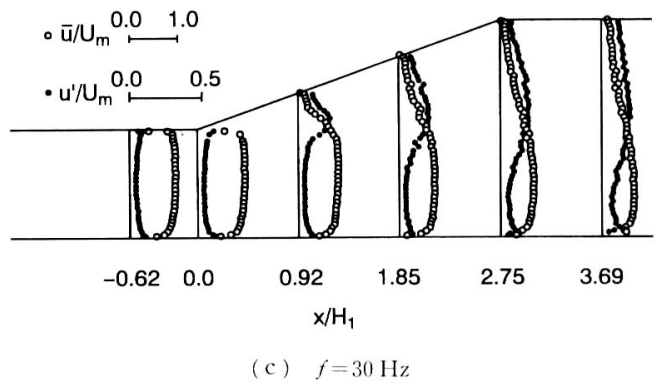

Fig. 6 Time-mean velocity and turbulent intensity distribution

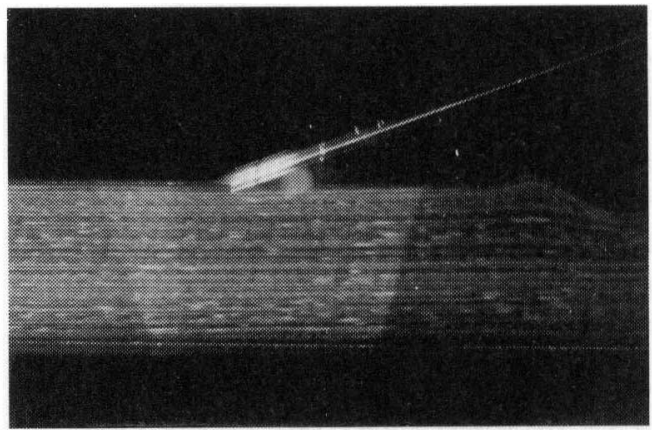

Fig. 7 Separating flow in diffuser. Visualized by hydrogen bubbles

の特徴が,この場合の同じ断面には認められない.こ れらのことから，はく離領域は $f= \pm 10 \mathrm{~Hz}$ の場合よ りさらに減少していることがわかる。なお, $f=-30$ 
$\mathrm{Hz}$ における平均速度分布は $f=30 \mathrm{~Hz}$ のものとほと んど同じである.

\section{$3 \cdot 3$ 位相平均速度分布 一つのかく乱の流入か} ら次のかく乱の流入までの間に, ディフューザ内でど のようなことが起こっているかを見るために, 各断面 における位相平均速度分布を求めた. 各測定位置にお ける位相平均速度と時間平均速度の差を $\Delta u(=\tilde{u}$ - $\bar{u})$ と表す.

図 8 に $f=30 \mathrm{~Hz}$ の代表的な位相における $\Delta u$ の分 布を, 図 9 に $f=-30 \mathrm{~Hz}$ のものを示す. 各 $x$ 断面に おける基準線の右側(左側)にプロットされている $\Delta u$ はその位置における時間平均值より, その位相におい て増速(減速)されていることを意味する。なお，ベル エントランス上流に示されている矢印はその方向に円 柱が移動していることを表している. 円柱が最初に入 口流路壁面と同じ $y$ 位置にきたときを位相 $\phi=0$ と定 義した.すなわち, 円柱の移動方向が正(負)の場合, $y / H_{1}=0.0\left(y / H_{1}=1.0\right)$ に円柱中心が一致したときが位 相零である. また, 次の円柱が同じ入口流路壁面の座 標に到達する時点を $\phi=2 \pi$ (1 周期) とする. 円柱が 入口流路の幅 $H_{1}(=65 \mathrm{~mm})$ を通過する時間は $0.26 \pi$ の位相差に対応する. 例えば, $f= \pm 30 \mathrm{~Hz}$ の場合, 1 周期は $33.3 \mathrm{~ms}$, 円柱が $H_{1}$ の距離を通過するのに要 する時間は $4.3 \mathrm{~ms}$ である.

図 8 に示す流れ場の時間変化について考察する. $=\pi$ の位相に扔いて, 入口直前の断面 $\left(x / H_{1}=-0.62\right)$ の $y / H_{1}=0.0$ 側に減速, 対面する壁面側 $\left(y / H_{1}=0.0\right)$ において増速が見られる。これが円柱の後流による減 速の影響である。これに対し， $\phi=0$ の位相では円柱 の後流は流入していないので, 当然のことながら,こ の $x$ 断面の速度分布には, このような減速および増速 が見られない.この $x$ 断面に後流の影響が最初に現 れるのは, 図には示していないが, $\phi=0.8 \pi$ のきで あった。これより下流の $x$ 断面において後流の影響 が速度分布に現れる位相(時間)とその $x$ 断面までの 距離から, かく乱の移動速度は $10 \mathrm{~m} / \mathrm{s}$ 前後と見積も れる。したがって, かく乱の移動速度は主流速度より 小さいことがわかる.

ディフューザ入口断面 $\left(x / H_{1}=0.0\right)$ の速度分布に, 後流による減速部分が見られなくなるまでの時間を, 後流の影響の持続時間とみなすことができる.図には 示していないが, $\phi=1.83 \pi$ に扔ける入口断面 $\left(x / H_{1}=\right.$ $0.0)$ の $y / H_{1}=1.0$ 付近に減速が認められ, $\phi=0$ にはそ れが認められなかった。このことから, $\phi=0.83 \sim$ $1.17 \pi(13.9 \sim 19.4 \mathrm{~ms})$ の間, かく乱の影響が持続する ことがわかる. 円柱が入口流路幅の距離を通過する時
間は短い $(0.26 \pi)$ にもかかわらず，これよりはるかに 長い時間にわたって円柱の後流が流入し続けることに なる。これは, 図 3 に示したように, 円柱がベルエン トランスから遠ざかった後も, 後流が流入するためで ある。

後流によるかく乱の移動速度 (約 $10 \mathrm{~m} / \mathrm{s}$ ), ディフ ューザ入口におけるかく乱の持続時間(約 $17 \mathrm{~ms}$ ) か ら,このかく乱の流れ方向の長さはほほ $170 \mathrm{~mm}$ と見 積もることができる.これはディフューザの長さとほ ぼ等しい。これらのことから，おおよそ次のようにい える、後流によるかく乱は、ほぼ半周期かかってディ フューザ入口に到達し, 残りの半周期でディフューザ 内を通過する。このかく乱の長さはディフューザ長さ と同程度であるから, 次にディフューザ入口にかく乱 が流入してくるとき, 前に流入した後流の後部がディ フューザ出口付近に残っている.このことは $\phi=\pi に$ おける速度分布において確認できる。すなわち， $x / H_{1}$ $=-0.62$ の断面における水平壁面付近の減速は新たな かく乱の頭部, $x / H_{1}=2.75$ における傾斜壁面近くに認 められる分散の大きな部分は先行するかく乱の後部に 相当する.これらのことから判断すると， $\phi=0$ の図 における断面 $x / H_{1}=0.92$ の減速部分は, 先行するか く乱の流入によるものである.

このような後流によるかく乱の流入によって, 各断 面では局所的な減速および増速が, 周波数 $f$ で繰返さ れる。これが, はく離せん断層の渦の巻上がり, 合体 の促進，に影響しているものと考えられる．かく乱周 波数 $f$ が $\pm 30 \mathrm{~Hz}$ のかく乱における波長 $\lambda\left(=U_{c} / f\right)$ を, $U_{c}=10 \mathrm{~m} / \mathrm{s}$ として見積もると, $\lambda=0.33 \mathrm{~m}$ であ る.これはディフューザの長さの約 2 倍である.ケル ビン・ヘルムホルツ不安定によって巻上がるはく離せ ん断層の渦の間隔は, 本実験条件では約 $30 \mathrm{~mm}$ 程度 である。したがって, 後流によって与えられる非定常 かく乱の波長 $\lambda$ はこれに対して約 10 倍長い.このよ うな長い波長のかく乱に対しては，いわゆる集団的合 体 (Collective interaction)が起こり, 大規模な渦構造 が形成される可能性がある(9).

図 9 に示す $f=-30 \mathrm{~Hz}$ の場合, このかく乱が $y / H_{1}$ $=1.0$ から 0.0 に向かって進行することを除けば, $f=$ $30 \mathrm{~Hz}$ の場合とほぼ同様である。例えば, $f=30 \mathrm{~Hz}$

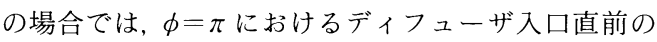
断面 $\left(x / H_{1}=-0.62\right)$ の $y / H_{1}=0.0$ 付近に, 大きな減速 が認められるが, $f=-30 \mathrm{~Hz}$ では同じ位相の同じ断 面においてそのような減速域は $y / H_{1}=1.0$ 付近に存在 する. 
$3 \cdot 4$ 非定常かく乱のディフューザ内への浸透

円柱の後流による非定常かく乱がもつ基本周波数 $f$ の速度変動がディフューザ内にどのように広がるの
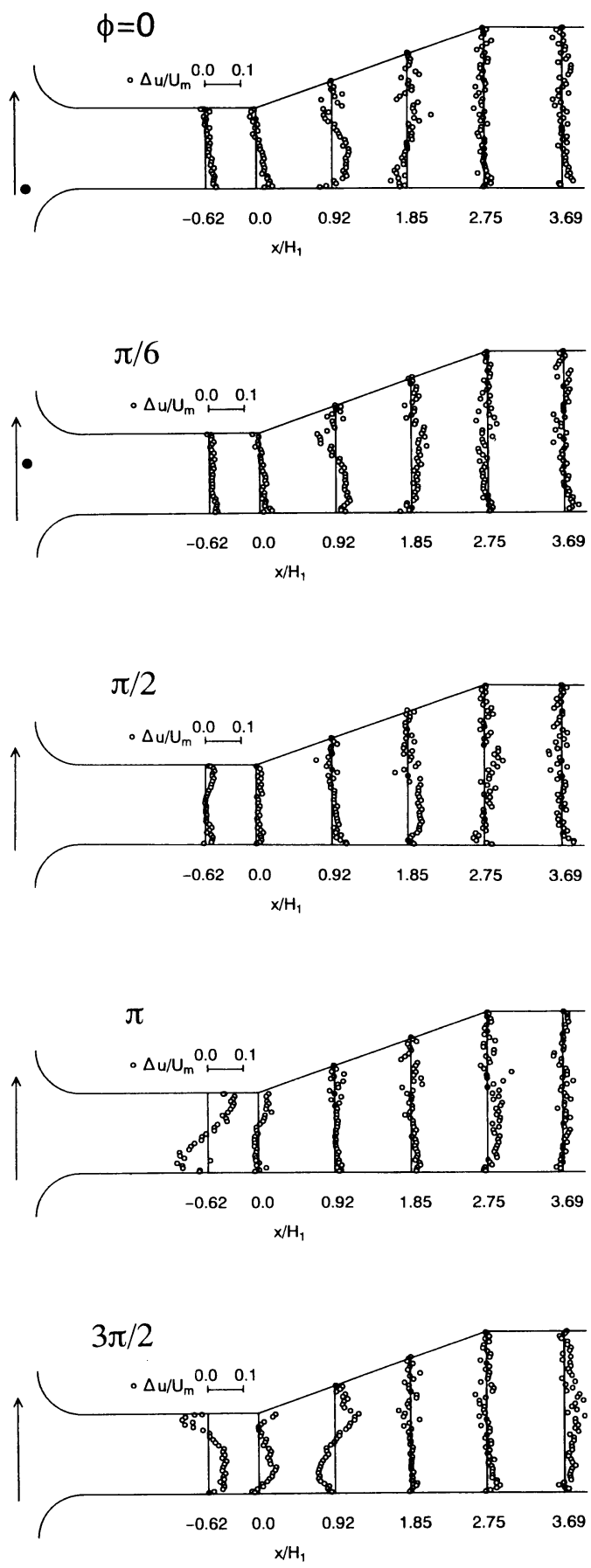

Fig. 8 Distribution of difference between phaseaveraged and time-averaged velocities $\Delta u$ $(f=30 \mathrm{~Hz})$
か, またどの領域においてその変動が増幅または減衰 するのかを調べるために, 各 $x$ 断面における速度変動 のスペクトルを求めた.
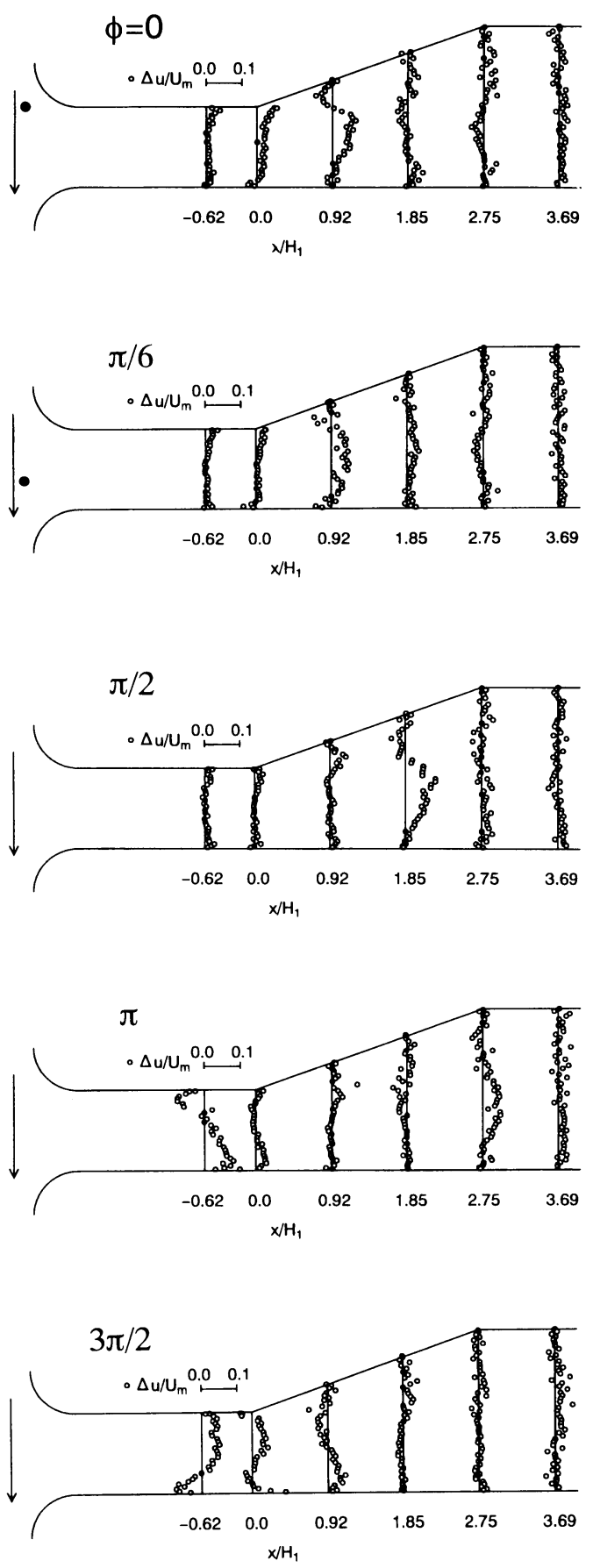

Fig. 9 Distributions of difference between phaseaveraged and time-averaged velocities $\Delta u(f=-30 \mathrm{~Hz})$ 


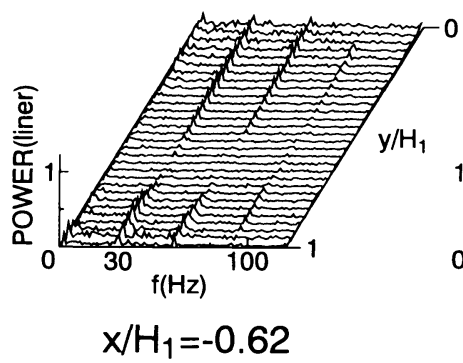

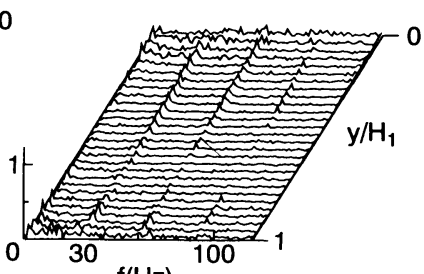

$\mathrm{f}(\mathrm{Hz})$

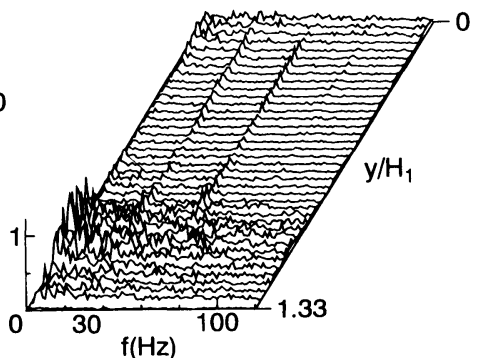

0.92

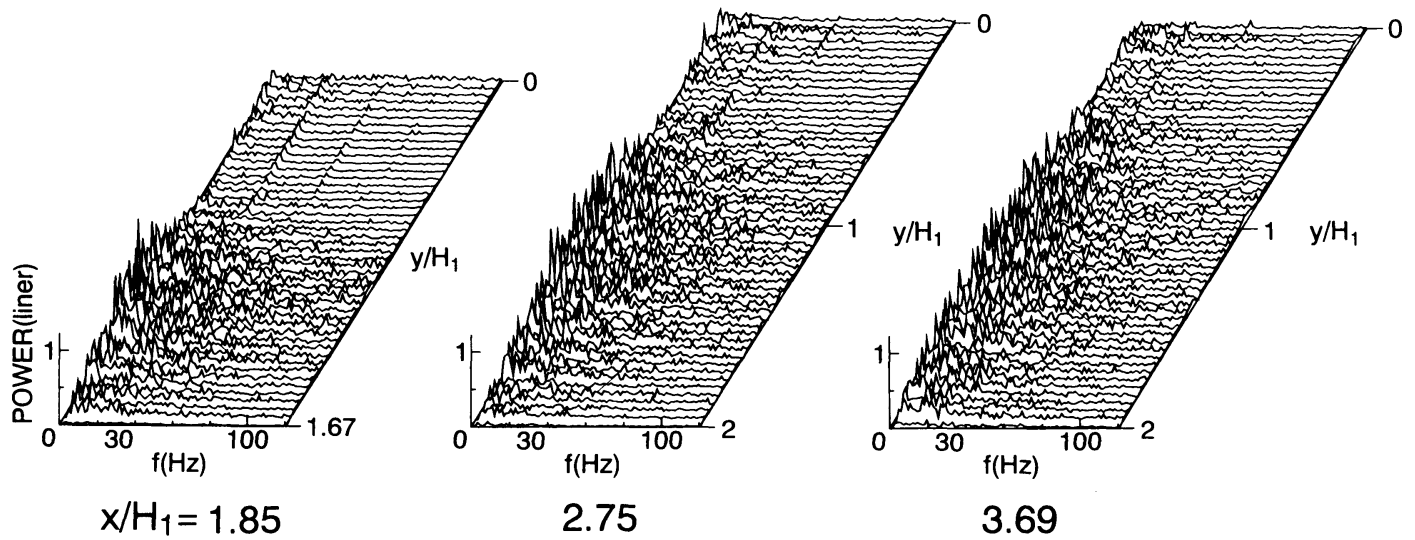

Fig. 10 Change of spectrum of velocity fluctuation at several $x / H_{1} . f=30 \mathrm{~Hz}$

図 10 は $f=30 \mathrm{~Hz}$ の非定常かく乱が流入したとき の, 各点に抢ける速度変動スペクトルを, 各 $x$ 断面ご との $y$ について, 三次元的に並べたものである。な お, 傾斜壁面側の変化をよく見えるようにするために, その $y$ 座標が手前側になるように配置してある。流 入させた非定常かく乱の基本周波数 $f=30 \mathrm{~Hz}$ を中心 に見ることにする。ディフューザ入口およびその上流 の断面 $\left(x / H_{1}=0.0,-0.62\right)$ では, 両方の壁面近傍にお いて $30 \mathrm{~Hz}$ の速度変動が認められる。しかし, $y / H_{1} \fallingdotseq$ 0.5 0.8の範囲ではこのかく乱による速度変動の周波 数が見られない. かく乱は入口流路断面内のいずれの $y$ 位置も通過するはずであるから,この周波数がどこ においても検出されていいはずである。この断面にお ける時間平均速度分布は一様であるから [図 6(a)], $y / H_{1} \fallingdotseq 0.5 \sim 0.8$ の範囲のかく乱は増幅することなく, 減衰したとも考えられる。しかし, 壁の近傍を除くほ とんどの範囲で, 速度はほぼ一定であることから, あ る狭い範囲でのみ減衰が起こったとは考え難い.

このことを位相平均速度分布の変化に戻って考えて みる. 図 8 に示した $x / H_{1}=-0.62$ における位相平均 速度と時間平均速度との差 $(\Delta u)$ の分布において, 1 周期間のそれの変化から, 増減速の振幅が大きな $y$ 位
置と, 時間平均速度のままほとんど変動しない $y$ 位置 が存在することがわかる.それは $y / H_{1}=0.67$ を中心 とする $y / H_{1}=0.50 \sim 0.85$ の範囲である。この範囲は 先に示した変動の周波数が見られなかった範囲と一致 する. $x / H_{1}=-0.62$ の断面の速度分布を時間をおい て見ていくと, かく乱の通過に伴う $\Delta u$ の分布の変化 は, あたかもディフューザ入口流路高さを半波長とす る定在波 (波長 $2 H_{1}$ ) のようである。また， $y / H_{1}=0.67$ 付近は節になっているように見える。非定常かく乱の 周波数がこれより高い場合には, 入口流路高さ $H_{1}$ の 間に，節が複数個現れることもあると考えられる。こ のように, 流れ方向にある周期で流入するかく乱によ って, 流れと直角方向に振幅が変化する速度変動が入 口流路内に誘起されることは新たな知見である.

ディフューザ内のはく離せん断層, およびはく離領 域内では, 流入するかく乱に対応する $30 \mathrm{~Hz}$ の周波数 ピークが存在するというわけではない. その外側の主 流中には $30 \mathrm{~Hz}$ の周波数にピークが存在する.ディ フューザの出口より下流の $x / H_{1}=3.69$ の断面では, この主流中におけるかく乱周波数の明確なピークを確 認することは難しい. したがって,このかく乱はディ フューザ内でエネルギーを失ったとみることができ 
る.

かく乱の傾きが上述の場合と逆の $f=-30 \mathrm{~Hz}$ にお ける, 速度変動スペクトルの変化では, $y / H_{1}=0.19 \sim$ 0.55 の範囲においてかく乱の周波数のピークが認めら れない，その範囲の中心は節である。このことを除け ば, かく乱の流入方向による違いはほとんど認められ ない。

\section{4. 結 論}

はく離を伴う片開き二次元ディフューザにおいて， 周期的に流入する非定常かく乱に対する圧力回復率お よび速度場の変化を調べた. 非定常かく乱は, ディフ ューザ入口上流において移動する円柱の後流である. 得られた結果を要約すると次のようになる.

（1）圧力回復率は非定常かく乱の流入によって増 加する. 非定常かく乱の流入周波数が高いほど圧力回 復率も高い.

（2）非定常かく乱である円柱の後流の, 主流に対 する傾きの正負はディフューザ内の流れ場に影響しな い.
（3） かく乱の流入周期に同期した局所的な減速お よび増速が, ディフューザ入口付近の壁面近くに誘起 される。

本研究は文部省科学研究費試験研究 (B) ( 1) No. 05555054 の援助を受けて行われたものであることを 付記する.

\section{文献}

（1）磯本馨 - 本阿弥真治, 機論, 51-471, B (1985), 3732--3736.

(2) Bhattachrjee, S., Scheelke, B. and Troutt, T. R. AIAA, 24-4 (1986), 623-629.

（3）木谷 勝・清水晶幸・望月 修・井門康司, 機論, 58-554, B (1992)，2953-2958.

(4) 武井伸郎 - 益田重明, 機論, 57-533, B (1991)，38-43.

（5）大泉・小尾晋之介・益田重明, 機論, 59-557, B (1993), 123 $-128$.

(6) Reneau, L. R., Johnston, J. P. and Kline, S. J., ASME, J. Basic Eng., 89-1 (1967), 141-150.

( 7 ) Eaton, J. K. and Johnston, J. P., AIAA, 19-9 (1981), 1093-1100.

（8）望月 修・木谷 勝・志摩裕介, 機論, 62-594, B (1996)、 454-460.

( 9 ) Ho, C. M. and Huerre, P., Ann. Rev. Fluid Mech., 16 (1984), 365-424. 